\title{
Brain gym therapy for children
}

\author{
Dina Indrati D Sulistyowati ${ }^{1}$, Remilda Armika Vianti ${ }^{2}$, Nur Azizah ${ }^{3}$ \\ ${ }^{1}$ Poltekkes Kemenkes Semarang, Indonesia \\ ${ }^{2,3}$ Nursing Department, Universitas Pekalongan, Indonesia
}

\begin{tabular}{l} 
ARTICLE INFO \\
\hline Article history: \\
Received: August 9, 2020 \\
Revised: August 20, 2020 \\
Accepted: August 30, 2020 \\
\hline
\end{tabular}

\section{Keywords:}

Play therapy gymnastics brain; Fine motor child; Age 4-6 years

\begin{abstract}
Child and adult health risks including obesity, hypertension and diabetes may be programmed by nutrional status during this period.. Approximately 5 to $10 \%$ of children are estimated to have developmental delays. Therefore, the need for stimulation so that soft motorik development in children to improve optimally. Therapy for brain gymnastics can be stimulated for to improving the soft motorik development of children.The purpose of this study was to determine the effect of brain gymnastics therapy on the development of soft motorik in 4-6 years of age.This research method is quasy experimental with non-randomized control group pretest-posttest design. With purposive sample. 42 respondents were divided into the control group and the intervention group. Soft motorik development of children before and after being given treatment by using gymnastics therapy of brain has increased 76.2 $\%$ with significantly $p$ value $0.045(<0.05)$. In conclusion the gift of brain gymnastics therapy can improve the motor development of children aged 4-6 years. Suggestions for schools, parents can provide premature stimulation by providing a brain gymnastics game that can stimulate child development.
\end{abstract}

This work is licensed under a Creative Commons Attribution 4.0 International License.

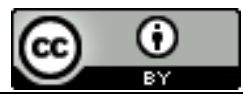

\section{Corresponding Author:}

Remilda Armika Vianti,

Department of Nursing, Universitas Pekalongan,

Jl.Sriwijaya No.3. Pekalongan, Jawa Tengah, Indonesia

Email: vivi.unikal@gmail.com

\section{INTRODUCTION}

Pediatricians should refer to existing services for nutrition support for pregnant and breastfeeding women infants and toddlers. Finally all providers caring for children can advocate for healthy diets for mothers, infants and toddlers. Finally all providers caring for children can advocate for healthy diets for mothers infants and young children in the first 1000 days. Prioritizing public policies that ensure the provision of adequate nutrients and healthy eating during this crucial time would ensure that all children have an early foundation for optimal neurodevelopment a key factor in long term health. In 2015 among US households with children 16,6\% (0r 6.4 milion housholds) were food insecure at some time during the year of households with children with incomes below $185 \%$ of the poverty line $36,8 \%$ were food insecure. Impoverished household are at increased risk of food insecurity but sudden social changes (for example divorce, loss of job) can introduce food insecurity into households that are not improverished [1].

Failure to provide key nutrients during this critical period of brain development may result in lifelong deficits in brain function despite subsequent nutrient repletion. Understanding the complex interplay of micro and macronutrients and developments key to moving beyond simply recommending a good diet to optimizing nutrient delivery for the developing child leaders in pediatric health and policy makers must be aware of this research given its implications for pub;ic policy at the and state level.

The nutritional environment has an effect on wether brain gowth and differentiation proceed normally or abnormally. Both adequate overall nutrition (absence of malnutrition) and provision of adequatea amounts of key macro and micronutrients at critical periods in development are necessary for normal brain development. Importantly the definition of malnutrition includes both undernutrition (provision of in adequate amounts of macro and or micronutrients) and also obesity (provision of excessive calories often at the expense of other crucial nutrients). 
The Special Supplemental Nutrition Program for Women, Infants, and Children (WIC) serves pregnant women, breastfeeding women (up to the child's first birthday), non-breastfeeding postpartum women (up to 6 months postpartum), infants (up to their first birthday), and children up to their fifth birthday. As such, it is the most important program providing nutritional support in the first 1000 days. In the United States, $53 \%$ of all infants younger than 1 year are served by WIC. According to the World Health Organization reports that 5$25 \%$ of preschool-age children suffer from minor brain dysfunction, including fine motor development disorders [2].

\section{RESEARCH METHOD}

This type of research is experimental quasy with the design of non-randomized control group pretest posttest design, in this study there were free variables and variables bound. This method of study uses the observation sheey using KPSP questionnairs (questionnaire pre-screening) [3]. Sampling techniques using purposive samples. The number of samples in this study of 42 respondents was divided into control groups and intervention groups.

\section{RESULTS AND DISCUSSIONS}

Table 1. Characteristics of Respondent

\begin{tabular}{lcc}
\hline Characteristics & Frequency & Percentage \\
\hline Age (Month) & 3 & \\
48 & 3 & $7,1 \%$ \\
60 & 18 & $42,9 \%$ \\
66 & 5 & $11,9 \%$ \\
72 & 16 & $38,1 \%$ \\
Gender & & \\
Male & 18 & $42,9 \%$ \\
Female & 24 & $57,1 \%$ \\
\hline
\end{tabular}

Table 2. Effect of brain gymnastics therapy for the child's fine motor development $(n=21)$

\begin{tabular}{lccc}
\hline \multicolumn{1}{c}{ Soft Motoric } & Pre & Post & p-value \\
\hline Mean \pm SD & $2,05 \pm 0,498$ & $2,38 \pm 0,669$ & \\
Possibility $(\%)$ & $2(9.5 \%)$ & $2(9.5 \%)$ & 0.020 \\
Doubt $(\%)$ & $16(76.2 \%)$ & $9(42.9 \%)$ & \\
Development $(\%)$ & $3(14.3 \%)$ & $10(47.6 \%)$ & \\
& & & \\
\hline
\end{tabular}

This result showed that in the majority of intervention groups experienced the subduing of fine motor development according to age from $4(19.0 \%)$ Respondents to $16(76.2 \%)$ Respondents, while in the control group were increasing but not as much as the intervention group, it was seen from 3 (14.3\%) Respondents to $10(47.6 \%)$ which has a smooth motoic development according to age. This results in showing that brain gymnastics can affect the development of child fine motor, it can be proved in the intervention group which is mostly motor development according to age. The research results with the Mann Whitney statistical test obtained a P value of 0045 . Decision making is done by looking at the degree of efficacy $(\alpha=0.05)$, i.e. when the $\mathrm{P}$ value of $<0.05$ then $\mathrm{H} 0$ is rejected. Current research because it is obtained by the value of $<0.05$, then there can be a meaningful difference between the development of the fine Motoik child 4-6 than in the control group and the intervention group seen from $\mathrm{P}$ value $0045(<0.05)$ so that it can be considered a therapeutic effect of brain gymnastics for fine motor development in children aged 4-6 in the sub-district of Surodadi subdistrict.

The increased physical complexity reflects the rapid rate of neuronal and glial growth and development within the brain. As these cells become more complex and interconnected, brain functional capacity increases. Some fundamental behavioral functions are already present at birth, implying that structural connectivity of the relevant brain circuits have begun. Examples of these early developing circuits include primary sensory systems such as hearing, touch and pain sensation, taste and, to a lesser extent, vision. More complex behaviors such as recognition memory, dependent in large part on hippocampal development, can even be demonstrated in the term and preterm neonate. Other brain functions that are being supported through this burst of circuit development and connectivity do not have obvious behavioral manifestations at birth. Despite the lack of behavioral manifestations, the neural circuits underlying more complex behaviors that will appear later in childhood are being constructed. For example, behaviors such as working memory, set-shifting, multi-tasking, and attention that are not present in the neonate nevertheless have their neural ontogenies prior to term birth. 
Therefore, attention to neurodevelopment in preterm and term infants is important not only for immediate function, but also for scaffolding for later-developing structures and circuits. The time period starting in the last trimester of pregnancy and progressing through the first 12-24 months post-term is characterized by the development of primary circuits that serve important functions. The brain regions and processes that are rapidly developing during this time period include the hippocampus and striatum that support fundamental declarative and implicit learning, respectively, myelination that supports speed of processing, and monoamine neurotransmitter systems that support reward processing. Optimal construction of these primary systems is key to proper development of later emerging higher order neural systems that rely on the fidelity of the early developing systems. For example, the later developing prefrontal cortex relies on initial connections from striatum and hippocampus early in life. Perinatal events that affect hippocampus and striatal integrity, such as nutrient/substrate restriction, result not only in abnormal function of these primary areas, but also in abnormal frontal lobe function. Thus, it is not surprising that attention deficit/hyperactivity behavioral phenotypes in middle childhood are more prevalent following intrauterine growth restriction

In this study, the researcher used a number of 42 respondents consisting of 24 daughters and 18 boys with an average majority age of 60 months. The research is divided into two groups of intervention groups and control groups in which each group consists of 21 children. Results of this study there was a significant influence on the treatment of brain gymnastics therapy for the child's fine motor development which can be seen in the results before and after the control group as well as in the results of measurements before and after MINGGU1 and the measurement results after Week 2 intervention group. In the control group obtained the Wilcoxon p value test of $0.020(<0.05)$ (Table 2); It can be concluded that there is a difference in the child's fine motor development between the before and after measurements of the control group. While the prior measurements and measurements after week 1 were researchers performed after intervention in the interventional group for 3 times a week with the Post Hoc Wilcoxon analysis Test in the results of P value 0.033 This indicates there is a difference between the before and after time of brain gymnastics intervention given for one week. One of the stimulation that can be given is brain gymnastics, where brain gymnastics helps the child to be able to utilize all of its natural brain potentials through movement and touch so that it will bring optimal tumbuh-kembang impact on the child [4]. Stimulation of brain gymnastics will significantly affect the development of the brain that will also affect the motor of the child in the frequency of training, the intensity of brain gymnastics performed, the length of time needed in training [5].

Brain Gymnastics exercises are very helpful in moving each limb, coordinating the movement, assisting the learning process, and adjusting daily activities, especially for children in the age of gold. Movement in brain gymnastics is relatively easy and can be done by anyone and is done at any time which does not require any special timing. The brain gymnastics movement is very well done in addition to optimizing the right brain performance and left brain gymnastics is also able to be intended to optimize fine motor skills, improve posture, increase energy and relax limbs. Brain gymnastics can be used as one of the stimulus media innovations to aid in the improvement of the child's fine motor, therefore for related institutions so that the development of children's motor is increased and optimal, this brain gymnastics stimulation activities can be done before the children will undergo learning activities or can also be used as an interlude during the time of rest [6]. Basically, in the exercise of brain gymnastics can be done routinely every day, but in order not to cause boredom in the children of brain gymnastics can be administered at least 3 times a week in approximately 30 minutes, enough to be given a movement with mild intensity to be easily followed by children. The more often the brain is given stimulation, the more optimal the growth and development of children. According to Wong stated that most of the brain gymnastics movements are faved by children because of simple movements and in accordance with the growth and development of motor children, namely enjoy active activities, happy jumping, drawing and writing [7].

\section{CONCLUSION}

There are differences in the fine motor development of children before and after in the control group with the mean result before 2.05 and mean after 2.38 with p-value $0.020(<0.05)$. There is a therapeutic influence to play brain gymnastics on fine motor development in the child Sia 4-6 years in the KINDERGARTEN of Surodadi village of Gringsing district of Batang with a value of $\mathrm{P}$ value $0.045(<0.05)$. In this study, there was a therapeutic influence of brain gymnastics treatment on the development of fine motor in children aged 4-6 years in the NURSERY village Surodadi in the subdistrict of the Gringsing district. The results of this research are also supported by the research results of Setianingsih which shows the influence of brain gymnastics on the ability of short-term memory in the young child tuna in the SLB Negeri Patrang Jember Regency. 


\section{REFERENCES}

[1] Ikatan Dokter Anak Indonesia, "Seputar Kesehatan Anak Mengenal Keterlambatan Perkembangan Umum Pada Anak," 2013. [Online]. Available: Http://Idai.Or.Id/. [Accessed 28 Februari 2017].

[2] R. Madyastuti, Lina and Fatiyah, "Pengaruh Terapi Bermain Puzzle Terhadap Perkembangan Motorik Halus Dan Kognitif Anak Usia Prasekolah (4-5 Tahun)," Journals of nurse community, vol. 7, no. 2, pp. 136-148, 2016.

[3] M. Dahlan and Sopiyudin, Statistik Untuk Kedokteran Dan Kesehatan: Dekriptif, Bivariat, Dan Multivariat, Jakarta: Epidemiologi Indonesia, 2015.

[4] A. Budiman, Mencerdaskan Iq \& Eq Anak Anda Melalui Kinerja Otak, Bandung: Pustaka Setia, 2016.

[5] Rochman and N. Susilo, "Pengaruh Latihan Senam Otak (Brain Gym) Terhadap Peningkatan Kemampuan Memori Jangka Pendek Pada Anak Tuna Grahita Ringan Di SDLB ABC Swadaya Kendal," Universitas Negeri Semarang, Semarang, 2015.

[6] Y. Supartini, Buku Ajar Konsep Dasar Keperawatn Anak, Jakarta, 2012.

[7] Setianingsih and Dince, "Pengaruh Senam Otak Terhadap Kemampuan Memori Jangka Pendek Pada Anak Tuna Grahita Ringan Di Sdlb Negeri Patrang Kabupaten Jember," Universitas Jember, Jember, 2012. 